\title{
Creation of Pamor's Knives as Business Diversification and Increase Sales Value Product Blacksmiths in Polanharjo District, Klaten Regency
}

\author{
Karju $^{1}$, Aji Wiyoko ${ }^{2}$, and Suyono ${ }^{3}$ \\ ${ }^{1}$ Lecturer at Craft Study Program, Faculty Fine Art dan Design, Indonesia Institute of the Arts in Surakarta \\ ${ }^{2}$ Lecturer at Keris Study Program, Faculty Fine Art dan Design, Indonesia Institute of the Arts in Surakarta \\ ${ }^{3}$ Keris maker in Klaten \\ E-mail: karju_karju@yahoo.co.id
}

\begin{abstract}
This study focused on the application of pamor Wos Wutah, Ngulit Semangka, Mrutu Sewu, Tunggak Semi into the shape of a stab knife, slice knife and cutting knife.the research focuses directed at the manufacture of various kitchen knife, cutting knife, and blades especially the skewer with the following considerations: (a) the economic potential of business creation will be achieved. (b) various alternative designs cutting knife, and stab knife patterned motif and developing traditional motif. (c) Trial manufacture prototype design and dissemination elected made by the craftsmen blacksmith in the Polanharjo district, Klaten. This research is a qualitative research using action research approach. The results of field observation there are various products of craftsmen in the villages of Kranggan, Keprabon and Segaran such as; (1) Kinds of kitchen household appliance include; Kitchen knives, shreds, shovel, and frying spatula. (2) Carpentry tools include; axe, hammer, chisel, plancong, scissor, and trowel. (3) Agricultural tools include; sickle, hoes, rakes, and crowbar. Most kind of production that produced is a kind of kitchen knives. Alternative designs produces around 50 types of blade design patterned pamor. Then selected into 4 selected design namely; The design cut blade of Nguntu Walang, design slice knife of Ngulit Semangka, design blade of Mrutu Sewu, and design cut knife of Mrutu Sewu. Those four chosen design are then created works to serve as a prototype training materials to the craftsmen blacksmiths (pande besi) in Polanharjo district, Klaten regency.
\end{abstract}

Keywords blacksmith, knife, pamor, design, and prototype.

\section{Introduction}

The pande besi craft center in Polanharjo is currently concentrated in the villages of Kranggan and Keprabon, Polanharjo district. In the hands of the pande besi craftsmen of this region, various products of metal crafts are produced, including sickle, hoe, hammer, axe (pecok), plancong, axe, knife, chisels ((tatah), and brick trowel (cethok). These villages are known as pande besi center is now being planned to be a tourist village tosan aji. The pande besi is directed to be willing to re-create tosan aji as a cultural icon and the origin of metal crafts in this region.

The potential of handicraft business in this region is quite big. It can absorb a lot of people to work spreading in each business units. The workers come from this region family, neighbors, and others. The rate of income of laborers and employers varies greatly depending on the size of the turnover of the business. In general the average income level of approximately Rp.1.350.000; or the average is still classified as a micro business. Beyond this micro business in this location there are also businesses that have large turnover which can reach Rp. 100,000,000. This level of income is calculated in October-November 2010 (Yayasan Insan Sembada, 2010).

Insan Sembada Foundation (Yayasan Insan Sembada) survey also found data that craftsmen in general are having some problems in developing their business. In general the problems faced by the craftsmen are as follows.

1. Each business unit has not recorded their business. Recording here is in the sense of doing business book keeping regularly and documented in a simple report. The flow of in and out funds is still mixed with income and other household needs. Approximately $80 \%$ of handicraft entrepreneurs have not recorded their business properly and regularly.

2. Diversification of products is still low. The number of product types is still limited to products produced from generations to generations. The speed of innovation in new product development is still running slowly. This causes the turnover of the business, and the market share has not grown significantly. Approximately $70 \%$ of entrepreneurs who have not made the business innovation continuously.

3. The capacity building efforts for business development are still minimal. Approximately $95 \%$ of craftsmen en- 
trepreneurs claimed that they have never attended business development training.

\section{Excisting Knife Product in Polanharjo}

During observation and interview the pande besi craftsmen in Polanharjo, we saw the production activities, tools, facilities, and their product. They were make knives with simple technologies and tools. We can see thinning and grinding of steel plate, and forging activity in besalen. One of knife craftsmen in Kranggan village which enough productive is UD Sarma.

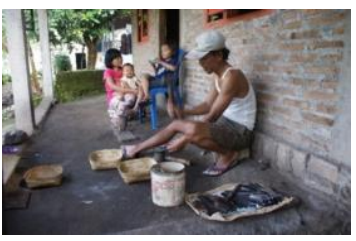

Figure 1

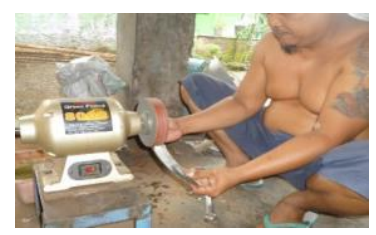

Figure 2

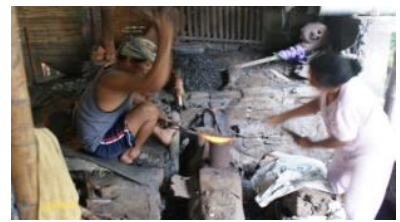

Figure 3

Figure 1, Agus is thinning the sharp side of the stainless steel plate for the knife; Figure 2, Mardi is grinding the knife of the stainless steel knife; and Figure 3 is a forging activity in besalen is $\mathrm{Mr}$. Slamet Widodo and his wife in Segaran village.

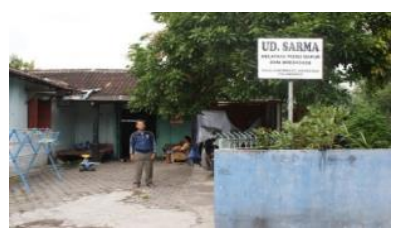

Figure 4

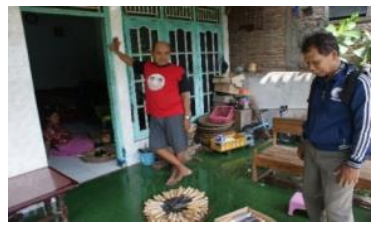

Figure 5

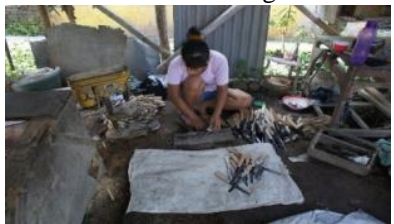

Figure 6

Figure 4, here is one of the knife craftsmen in Kranggan village who have business license; Figure 5, the interviews with Mr. Wikan (The owner of UD Sarma) about the knife product that has become a hereditary profession; and Figure 6, that is the daughter of Mr. Selamet Widodo named Bekti is installing the handle of the knife.

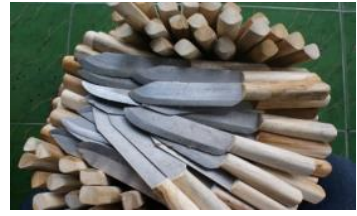

Figure 7

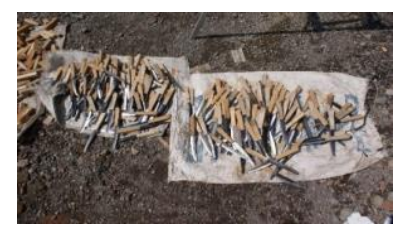

Figure 8
Figure 7 and 8, those are knife products by UD Sarma that have been fitted with handles and ready to be sold in the market.

UD Sarma's production activities produce simple products like the above example. In fact it is quite potential to be developed into a more quality product and has more selling value and significant economic impact for the welfare of craftsmen.

\section{Developing Knife Product}

Based on the results of data processing, the researcher went to the next stage of designing the pamor blade design for the development of tosan aji in Polanharjo village. The next stage is making the design of pamor blades and design determination is selected.

1. Alternative design of pamor knife

Base on the collecting data, researcher create alternative design for developing their product in Polanharjo district. The various pamor knife have created. Pamor to be applied is a kind of iron pamor such as pamor Mrutu Sewu, Nguntu Walang, Wos Wutah, Ngulit Semangka, and Udan Mas. For more details, it can be seen in the design description and its description below.

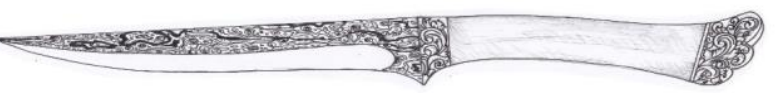

Figure 9. Alternative design of pamor knife Mrutu Sewu (Design by Suyono, 2016)

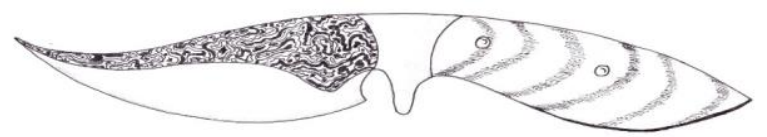

Figure 10. Alternative design of pamor knife Nguntu Walang (Design by Suyono, 2016)

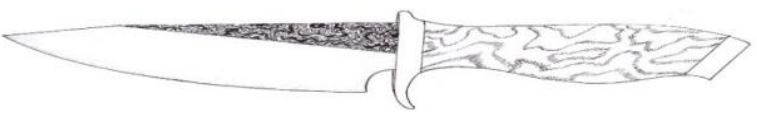

Figure 11. Alternative design of pamor knife Wos Wutah

(Design by Suyono, 2016)

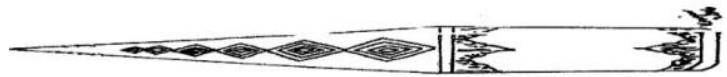

Figure 12. Alternative design of pamor knife Wos Wutah by Suyono, 2016)

(Design

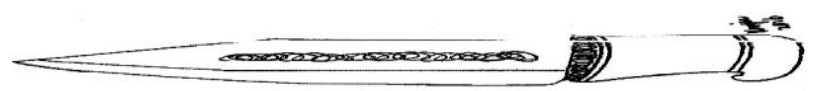

Figure 13. Alternative design of pamor knife Potongan Bawang Merah (Design by Karju, 2016)

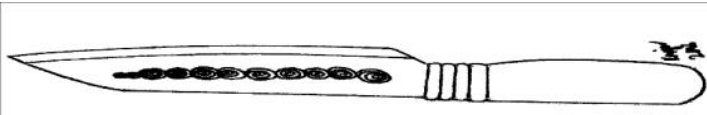

Figure 14. Alternative design of pamor knife Kacang-Kacangan (Design by Karju, 2016)

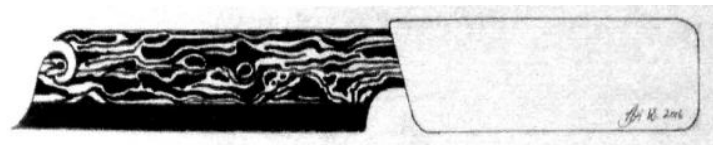

Figure 15. Alternative design of pamor knife Kulit Bawang Merah (Design by Aji Wiyoko, 2016) 


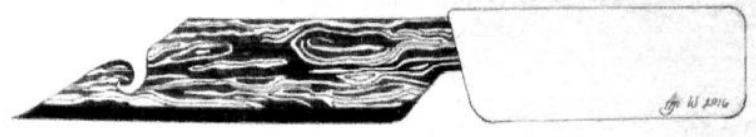

Fig. 16. Alternative design of pamor knife Ngulit Semangka (Design by Aji Wiyoko, 2016)

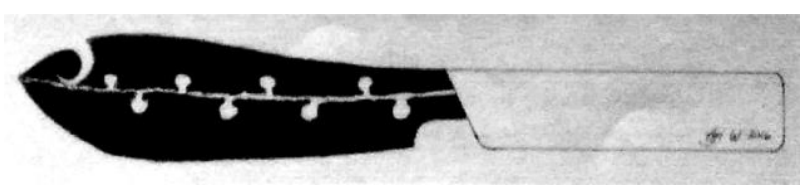

Fig. 17. Alternative design of pamor knife Sekar Polo (Design by Aji Wiyoko, 2016)

\section{b. Design of pamor knife selected}

The criteria used for selecting a variety of alternative designs of the pamor knives into the chosen designs is by using the theory of theory of utility. This theory is based on usability, showing that all artistic activity is all aimed for practical and social needs (Karju, 2004:45) This theory implies that the born of art supported by social and economic needs is the mainstay or the base of human activity. The presence of art is closely related to crafmanship and the presence of art is not an abstract but the skill of work and the desire to enjoy the results. And the born of art has something to do with the psychological process, the desire of the human psychology to admire every result of his work. Another reference used for selecting alternative designs is that in fine art design and design the outline not only observes the design object as a functional difference, but more about the meaning contained in the design. In addition, the design object can be seen as a cultural object (Yan Yan Sunarya, 2016:1) .

The existence of the design used to give a touch of creativity need a sense of creativity. Intelectual is needed in the design process (ratio, logical, thoughts, and ideas). In addition creativity and design a mutualistic relationship, as a physical cultural work order, is a consideration to maximize the idea of thought, taste and soul of the designer. It is no less important in doing the selection of design is the existence of design innovation, especially related with creative economy, Products, functions, ergonomics and uniqueness, economics, and value of science and technology (Yan Yan Sunarya, 2016:3). In addition to the existence of visual design can also be selected by viewing the pragmatic power, which is looking for hidden intentions of cultural background, the existence of types of pamor, the knowledge of the craftsmen pande besi in Kahuripan culture in the villages of Segaran, Keprabon, and Kranggan.

Based on the criteria mentioned above then selected 4 designs as follows:

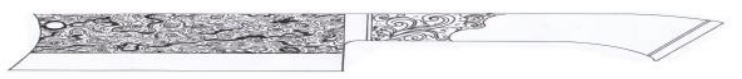

Fig. 18. Design of pamor knife Mrutu Sewu. Specification: Kind of knife: cut, split (with thick and wide knife shape, so strong and sturdy knife, more useful for cutting and splitting hard objects). (Design by Suyono, 2016

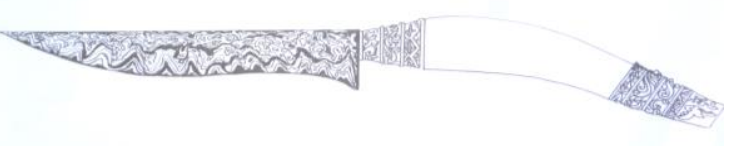

Figure 19. Design of slicing knife with pamor motif Nguntu Walang. Specification: Type of knife: slicing, puncture (The sharpness side on both the lower and upper side of the knife is more suitable for the type of slicing knife, with the function of cutting meat or objects less hard tends to be soft). (Design by Suyono, 2016)

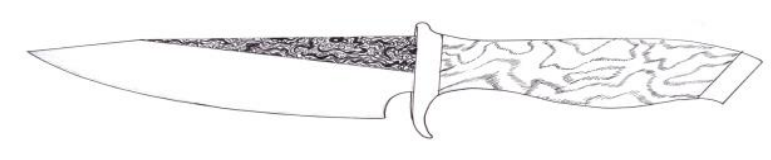

Figure 20. Design of slice, puncture knives, pamor Wos Wutah Specification: Type of knife: slice, puncture (The sharpness of this knife is in the lower side and in the edge, so it is more suitable for piercing forward and sharp on the curved bottom side more useful for slicing or cutting a soft object) (Design by: Suyono, 2016)

\section{Realization of Pamor Knife Prototype}

After the best design of the pamor blade, the next step is to embody the design into a pamor knife product. Of the four best figures above (see Figure 18-21), the researcher decided to realize the design of slicing knife with the motives of Nguntu Walang (see Figure 19) to be the product of the pamor blade.

Selection of wrought iron material is done by selecting fiber or vein of soft iron, it is not rough (agal) and has characteristic of fiber that is flat porous. After the material is prepared then wrought iron is cleaned from dirt, rust and compound materials that interfere with doing this way, the iron is heated until become red smold then it is wrought repeatedly, again and again reheated and forged again until the iron is estimated clean from the dirt, silicon or other metal substance. It is also called as an iron refining. Furthermore wrought iron is united with the pamor material, for this process using nickel material $(\mathrm{Ni})$ as the supporting material of the pamor. In addition to nickel, pamor material originally used meteorite or meteorite stone (star stone) to make it, this stone contains titanium so it is very hard, heat resistant, rustproof, and the color is shiny white silvery. Because to get the meteorite is very difficult and it is not sold freely in the market then with a variety of research now 
many people use of nickel material as a replacement material. After the nickel material is prepared then the forged flakes are processed more or less with a thickness of $3 \mathrm{~mm}$ in width and the same size between wrought iron materials that have been prepared previously. Then the wrought iron is formed by resembling the letter $\mathrm{U}$ or $\mathrm{Z}$, which then in the middle of the iron material was inserted nickel material that has been flatten before.
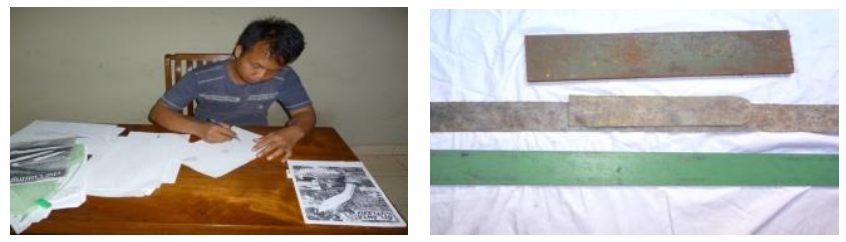

Figure 22, Suyono is making work drawings to make prototype works. Figure 23, the main ingredient used to make a pamor knife which includes: Wrought iron weighing $15 \mathrm{~kg}$, Steel 01 weighing $3 \mathrm{~kg}$, Nickel weighing 500 grams, and wood.

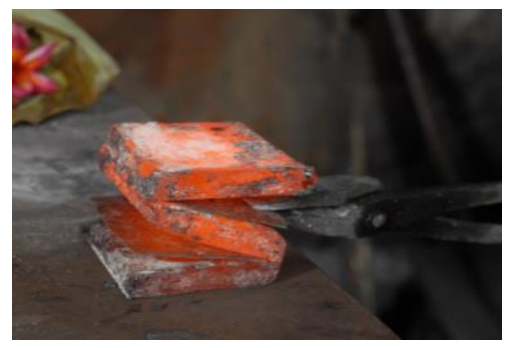

Figure 24. The filling of nickel in wrought iron as a pamor material.

The Nickel is heated to $1000^{\circ} \mathrm{C}-1200^{\circ} \mathrm{C}$ and then forged many times in order to attach and unify the two metal materials and form a tightly tightened square and can be mixed with borax powder $\left(\mathrm{Na}_{2} \mathrm{~B}_{4} \mathrm{O}_{7} 10 \mathrm{H}_{2}\right)$ by sowing on the surface of wrought iron to reduce oxidation, since both materials must be attached together. If the temperature is less heat or the fitting does not fit according to the forging then the possibility of iron and pamor which does not blend can peel or crack if later continued in the process of formation. If you want a soft pattern of pamor then produced it by making more on folding the pamor, and vice versa if you want a pattern of large pamor then folding under 80 curves only.

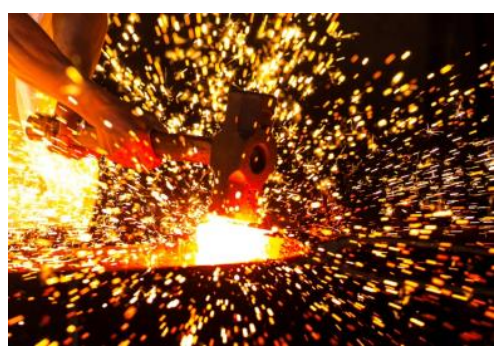

Figure 25. The process of forging (unification of wrought iron with nickel).

For pamor that is applied to the blade this time using the pamor Nguntu Walang, with the number of folds up to 64 curves or layers to make pamor somewhat large (agal) so it will be clearer when creating a pattern that makes up the shape to resemble a grasshopper's teeth (Nguntu Walang). After the number of folding has been enough to make the pattern of pamor Nguntu Walang, then the next stage of the global shape of knife blades according to the design and type of knife as wanted. After the global shape of the blade is completed then continued to the formation of the knife detail until the point of sharpness is all done at this stage.
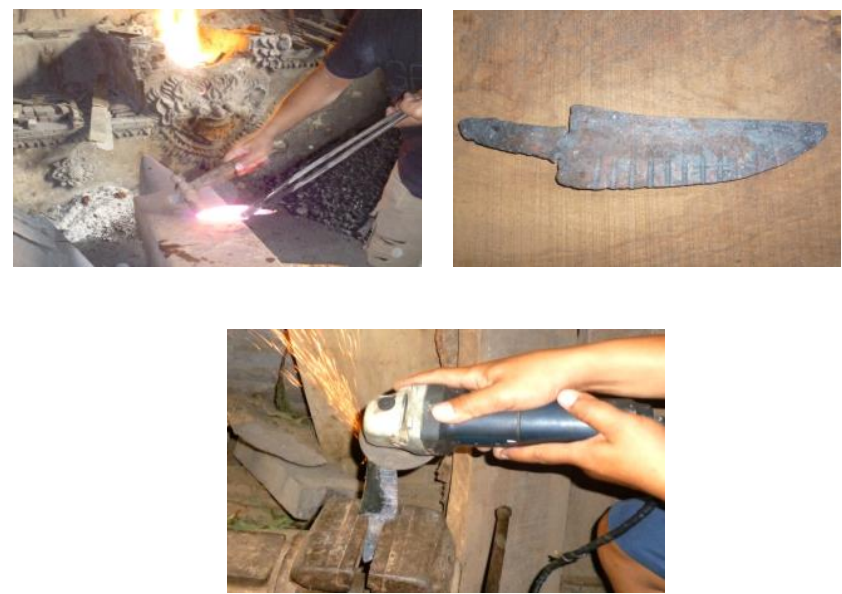

Figure 26 (left), the process of forming the pattern of pamor Nguntu Walang, the process is using drip or chisels (betel) which is unsharping by placing on drip at the end of the blade which will imprint according to the wound produced in the drip or that chisels (betel). Figure 27 (right), a knife material in gedeq to create a pattern of pamor Nguntu Walang. Figure 28 (bottom), the formation of knife detail with grinding tool machine.
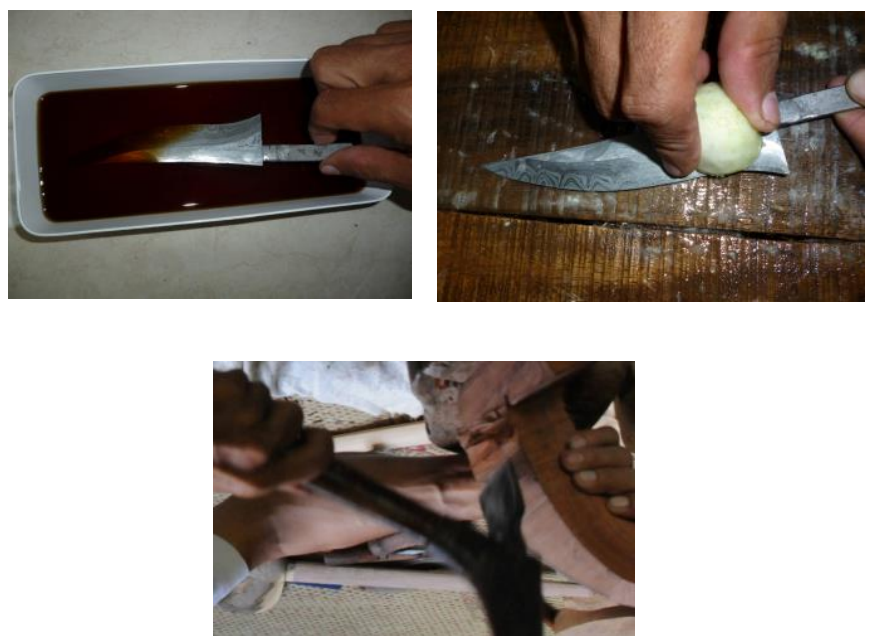

Figure 29 (left) that is coating a blade with a warangan solution made of lemon juice and a solution of warangan. Besides it is corrosion resistant, this mewarangi process also serves to show a clear pattern of pamor knife, contrasting colors between iron, steel and pamor, it will also add the impression of beauty on the blade. Figure 30 (right), is the process of cleaning the pamor blade with a lime. This process is done after the plating process (penyepuhan) is completed. Figure 31 (bottom), after the blade knife process is completed then continuing to the complementary stage and supporting accessories of the knife that is making upstream or handel from acacia auriculiformis a.conn wood. This wood is chosen because the fiber is smooth, beautiful and light. 
Agung Lestari.
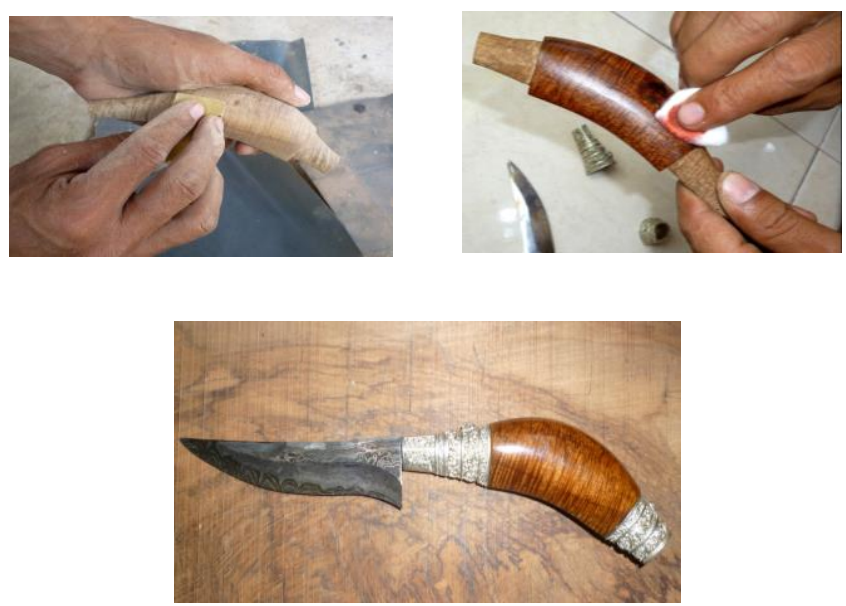

Figure 32 (left), the process of smoothing the handle of the blade with wooden sandpaper. Figure 33 (right) is a finishing process of handle knives by varnishing. Figure 34 (bottom). The result of my work pamor knife Nguntu Walang.

\section{Conclusion}

The existence of pande besi in the villages of Kranggan, Segaran and Keprabon is still very productive in maintaining their business to meet the needs of their life. The working of pande besi is not only done by men only, but also done by adolescent women even teenagers. It is very concerned that most of pande besi in managing their business, starting from management, the production process until the marketing process is still done traditionally. Nevertheless, their skill in making various kitchen knives and agricultural tools is undoubtfull. This potential allows to be improved both the knowledge and skills in making kitchen knives with pamor. This is done to produce a variety of knife creations are more qualified. This effort can be a diversification of products in marketing so that at the end it help to increase the selling value of some products produced by the pande besi in Klaten.

\section{References}

[1] A.N.J. Th a Van der Hoop. 1949. Variety of Jewelry Indonesia (Ragam-ragam Perhiasan Indonesia). Utgegeven Door Het Konjlkt Bataviaach Genooptshap van Kunsten Wetenschappen.

[2] Anderson, Benedict. 2000. Javanese Mythology and Tolerance (Mitologi dan Toleransi Orang Jawa), Qalam: Yogyakarta.

[3] Arifin. MT. 2006. Javanese Keris, Blades, History, and Markets (Keris Jawa, Bilah, Latar Sejarah), Hingga Pasar. Jakarta: Hijiet Pustaka.

[4] Agus Sachari. 1987. Art Design, between Conflict Technology and Harmony (Seni Desain antara Teknologi Konflik dan Harmoni). Nova Bandung.

[5] Bambang Hasrinuksmo. 1995. Pamor Keris. Jakarta: CV
[6] 2008. Keris Encyclopedia (Ensiklopedi Keris). Jakart: PT Gramedia Pustaka Utama.

[7] Basuki Teguh Yuwono. 2012. Keris Indonesia, Surakarta: Citra Sain.

[8] Claire Holt. 2000. Tracking the Development of Art in Indonesia (Melacak Jejak Perkembangan Seni di Inonesia), (translated by RM Soedarsono from Art in Indonesia : Continuties and Cange)., Bandung : Masyarakat Seni Pertunjukan Indonesia.

[9] Davit Van Duren. 1998. Krisses a Sertikal Bibliography. Netherlands: Wijk en Aalburg.

[10] Dharmosoegito. 1961. Dhuwung Winawas Sawetawis I dan II. Surabaya: Jajasan Djojobojo.

[11] FL, Winter. 2009. The Classical Book About Keris (Kitab Klasik tentang Keris). Yogyakarta: Panji Pustaka.

[12] Haryono Haryo Guritno. 2006. Javanese Keris between Mystics and Reason (Keris Jawa Antara Mistik dan Nalar). Jakarta: PT Indonesia Kebanggaanku.

[13] Karju. 2016. The creation of Various Knives Pamor as Diversification and Increasing the Value of Blacksmith Products Selling in Kecamatan Polanharjo Klaten Regency (Kreasi Aneka Pisau Pamor sebagai Usaha Diversifikasi dan Peningkatan Nilai Jual Produk Pande Besi di Kecamatan Polanharjo Kabupaten Klaten). Research report. ISI Surakarta. 